\title{
Postsekularyzm a literatura. Przykead Edwarda Stachury
}

\author{
Anna KoŁos \\ kolos.ann@gmail.com
}

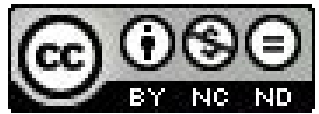

\section{WPROWADZENIE}

W humanistyce polskiej ostatnich lat zdiagnozować można pewien szczególny zwrot w opracowaniach historycznoliterackich i monografiach autorów. Próbując dokonać pobieżnej syntezy, można stwierdzić, iż prymat ideowy lat dziewięćdziesiątych wyznaczały badania intertekstualne, mniej lub bardziej obficie czerpiące z przyswajanego w kraju instrumentarium ponowoczesnego. W tym okresie badaniom przyświecała Derridiańska idea il n'y a pas de horstexte, „nie ma nic poza tekstem”. Choć trudno o jedna, kanoniczną wykładnię formuły Jacquesa Derridy, klarownego wyjaśnienia tendencji „tekstualnej” dokonał Jonatan Culler w niezwykle - swego czasu - popularnym zbiorze Interpretacja i nadinterpretacja, pisząc, iż dekonstrukcja: „podkreśla, że znaczenie jest związane z kontekstem - jest funkcją relacji wewnątrz tekstu lub między tekstami, że sam kontekst nie jest niczym ograniczany: zawsze znajdą się nowe możliwości kontekstowe, wyznaczanie granic jest zatem jedyną rzecza, której zrobić nie możemy"1.1.

Za reprezentatywną pracę dla tego okresu literaturoznawstwa w Polsce uznać można przede wszystkim Sylwy współczesne Ryszarda Nycza, których drugie wydanie przypadło na 1996 r. ${ }^{2}$. Można dalej zaryzykować twierdzenie, że gruntowna zmiana w postrzeganiu tekstu jako intertekstualnej siatki znaczeń, ,,kradzionych” z innych tekstów, dokonała się około połowy mijającego właśnie dziesięciolecia. Nieprzypadkowo w tym właśnie czasie, dokładnie w 2006 r., ukazała się praca zbiorowa Kulturowa teoria literatury pod redakcją Michała Pawła Markowskiego i Ryszarda Nycza. Artykuł pierwszego z redaktorów, Antropologia, humanizm, interpretacja sygnalizował prymat nowego horyzontu poznawczego, w ramach którego w tekście przestano dopatrywać się gry znaków, a zaczęto poszukiwać doświadczenia człowieka. W artykuł badacza wpisane zostały również zdecydowane postulaty literaturoznawstwa ukierunkowanego antropologicznie:

„Kategoria doświadczenia pozwala, jak sądzę, ominąć skrajne bieguny uniwersalnych teorii i jednostkowego bełkotu i w tym sensie jest podstawową kategorią antropologiczna, która opisuje człowieka zanurzonego w życiu i starającego się o tym życiu powiedzieć coś innym po to, by inni mogli go zrozumieć. Jeśli jednak zgadzamy się na to, że kategoria ta może służyć za sprawne narzędzie opisu życia, to powinniśmy także zgodzić się na to, że jest to zręczna kategoria literaturoznawcza, chyba że zakładamy między życiem a literaturoznawstwem nieprzekraczalną różnicę. [...] Kto zaś niczego o życiu powiedzieć ciekawego nie potrafi, literaturą w ogóle nie powinien się zajmować"3 .

W centrum zainteresowania badaczy, którzy „potrafili powiedzieć coś ciekawego”, miały się znaleźć doświadczenie, podmiotowość, ciało. Za względnie paradygmatyczny przykład książki świetnie realizującej aktualne zagadnienia poznawcze uznać można Czarny nurt Markowskiego opowiadający o autorze, o którym mogłoby się wydawać, że powiedziano już tak wiele - o Wi-

1 J. Culler, W obronie nadinterpretacji, [w:] U. Eco (red.), Interpretacja i nadinterpretacja, Kraków 1996, s. 119.

2 R. Nycz, Sylwy współczesne, Kraków 1996.

3 M. P. Markowski, Antropologia, humanizm, interpretacja, [w:] M. P. Markowski, R. Nycz (red.), Kulturowa teoria literatury. Główne pojęcia i problemy, Kraków 2010, s. 150. Podkreślenie-A. K.

4 Tenże, Czarny nurt. Gombrowicz, śziat, literatura, Kraków 2004. 
toldzie Gombrowiczu. Zgodniez krótko zarysowanymi wyżejintencjami badawczymi oryginalność autora Ferdydurke literaturoznawca upatrywał w doświadczeniu rzeczywistości, pisząc:

„żaden z polskich pisarzy (może poza Leśmianem i Białoszewskim) nie włożył tyle wysiłku w wynalezienie języka (nie chodzi tu bowiem o „ustawianie” języka, ale o jego wynajdywanie), którym można by coś powiedzieć o tej arogancko rozpostartej "połaci nieokreślonego", jaką jest świat [...]. Żaden nie przyznał się tak szczerze, że świat nieustannie obsuwa się w demoniczną niezrozumiałość, z którą nie wiadomo co począc $c^{\prime \prime 5}$.

Opisywana zmiana $\mathrm{w}$ zainteresowaniach literaturoznawczych w ostatnich kilku latach, zwrot ku utekstowionemu doświadczeniu i podmiotowości w miejscu badania tekstowych związków słów, poza które literatura rzekomo miałaby nie wykraczać, mogą dowartościować twórczość poetycką i prozatorską Edwarda Stachury, która nie miała szansy na poważniejsze zainteresowanie $\mathrm{w}$ ramach minionych modeli humanistycznych. Markowski, choć w swoich syntezach literaturoznawczych - niesłusznie - nie dostrzega poety na mapie nowoczesności, jako propagator zwrotu antropologicznego i zmiany w badaniach literackich, może pośrednio przyczynić się do zainteresowania tą twórczością w nowych kontekstach poznawczych.

\section{POSTSEKULARNE KIERUNKI INTERPRETACJI}

Można w takiej roli widzieć nowego bohatera na scenie nowego paradygmatu humanistycznego, którym jest dyskurs postsekularny, pozwalający widzieć w różnorodnych wątkach filozoficznych scalającą obecność, bardziej lub mniejjawna, podstawowych kategorii teologicznych ${ }^{6}$. Odejście od oświeceniowej, zsekularyzowanej wizji nowoczesności i dążenie do ponownego zaczarowania zdezintegrowanego podmiotu nadają kategoriom porządkującym filozofię tekstów Stachury szczególnego posmaku „,religijności”, , ,fideistycznego irracjonalizmu", mimo że-jak wiadomo-podmiot tekstowy nie deklaruje ani wiary w Boga judeochrześcijańskiego, ani w abstrakcyjny absolut europejskiego idealizmu. Agata Bielik-Robson swoją książkę Na pustyni poświęciła właśnie tropieniu utajonych założeń teologicznych $w$ filozofiach europejskich, stwierdzając:

„Wydaje się bowiem, że nawet najbardziej nieprzejednanie świecka filozofia w pewnym kluczowym momencie dokonuje mniej lub bardziej arbitralnego wyboru, którego później wiernie strzeże, otaczając go specyficzną formą kultu" ${ }^{\prime \prime}$.

Jeśli zgodzić się, iż filozofie tak świeckie, jak i racjonalne posiłkują się kategoriami zaczerpniętymi z porządku fideistycznego, to przyznać trzeba, iż projekt podmiotowości w tekstach Stachury, odrzucający zwulgaryzowane profanum nowoczesności, cały osnuty jest wokół wyborów o naturze teologicznej. $\mathrm{Z}$ jednej strony projekt nowego podmiotu stanowi obietnicę wyzwolenia o charakterze inicjacji religijnej, która nie ustanawiałaby prawdy bez kategorii fideistycznych: pistis (wiara, przekonanie), agape (miłość), elpis (pewność), które wymienia Alain Badiou w Świętym Pawle?. Z drugiej natomiast - wizja genezy podmiotu, zakorzeniona w filozofii zachodnioeuropejskiej, zdradza wspólne dla wielkiej formacji „od Jonii po Jenę"10 przesłanki, które współczesna rewizja odczytuje jako kryptoteologiczne. Następuje zatem wprzężenie

\footnotetext{
Tamże, s. 14. Podkreślenie - A.K.

Por. A. Lipszyc, Ślad judaizmu w filozofii XX wieku, Warszawa 2009, s. 21.

A. Bielik-Robson, Na pustyni. Kryptoteologie późnej nowooczesności, Kraków 2008, s. 7-8.

Tamże, s. 8-9.

A. Badiou, Święty Pawet. Ustanowienie uniwersalizmu, Kraków 2007, s. 26.

10 Przeciwstawienie Aten i Jerozolimy występuje przede wszystkim w pismach Lwa Szestowa i Franza Rosenzweiga. Zob. A. Bielik-Robson, Na pustyni..., dz. cyt., s. 24.
} 
wielowiekowych wyobrażeń wspólnoty europejskiej w nową procedu urę ${ }^{11}$ prawdy, dążącą do objawienia.

Cofając się w genezie podmiotu ad fontes, trzeba rozpocząć refleksję od fenomenu pierwotnej negatywności, określającego „prymarny horyzont teologiczny każdego myślenia” ${ }^{12}$. Jak pisze Bielik-Robson:

„Powodem, dla którego człowiek nie może całkiem oderwać się od namysłu nad sprawami ostatecznymi, jest niewykorzenialna negatywność leżąca u samych źródeł jego relacji ze światem - albo, ujmując rzecz prościej, świadomość śmierci. Śmierć wsuwa między człowieka a świat niewidzialną przesłonę, która sprawia, że człowiek nigdy nie uczestniczy w pełni w otaczającym go spektaklu istnienia"13.

Tak zarysowana perspektywa znajduje potwierdzenie w intuicjach współczesnej antropologii kultury, o czym świadczą przekonania Clifforda Geertza:

„żyjemy, jak to zgrabnie ujął któryś z pisarzy, w »informacyjnej luce«. Pomiędzy tym, co nam mówi nasze ciało, a tym, co musimy wiedzieć, by móc funkcjonować, znajduje się próżnia"1"1.

Informacyjna luka czy świadomość śmierci uniemożliwiają podmiotowi zakorzenienie w świecie, prowadząc do jego separacji. Antropologia generatywna w ujęciu Erica Gansa określa, że tym, co wyrywa ze stanu naturalnego i odróżnia człowieka od zwierząt, jest umiejętność reprezentacji, która tworzy wariacje wyobrażeń kulturowych, ustanawiających fikcyjne narracje wypełniające pierwotną próżnię ${ }^{15}$ i odpowiadające na nieuniknioność traumy. Informacyjna luka oddziela podmiot od świata i warunkuje odczucie podziału na podmiot i przedmiot, ,ja" i „nie-ja”. O ile zatem pełnia doświadczenia wydaje się niemożliwa, człowiek skazany jest na poszukiwanie „szczelin istnienia” w hermetycznej rzeczywistości.

W polskiej literaturze późnej nowoczesności świadomość tak rozumianej negatywności poznania nie była rzadkością. Zdecydowanie najdonioślej brzmi w tej materii głos Zbigniewa Herberta, którego Drewniana kostka jest jednym z najlepszych przykładów samoświadomości paradoksów filozofii zachodnioeuropejskiej w polskiej literaturze powojennej:

„Drewnianą kostkę można opisać tylko z zewnątrz. Jesteśmy zatem skazani na wieczną niewiedzę o jej istocie. Nawet jeśli ją szybko przepołowić, natychmiast jej wnętrze staje się ścianą i następuje błyskawiczna przemiana tajemnicy w skórę. Dlatego niepodobna tworzyć psychologii kamiennej kuli, sztaby żelaznej, drewnianego sześcianu"16.

W ujęciu Herberta podmiot zatem, trwale odseparowany od przedmiotu w filozofii zachodnioeuropejskiej, skazany jest na epistemiczną traumę „wiecznej niewiedzy o istocie”.

Nowoczesne i racjonalne filozofie przyjmujące pogląd reprezentacjonistyczny, inkorporując istnienie owej „,szczeliny" i przekonanie o niemożliwości zintegrowanego poznania, odrzucające żywiołowy witalizm pojednania bytu i egzystencji, mogą być nazwane - za Bielik-Robson

\footnotetext{
11 Procedurę prawdy należy tu rozumieć jako splot możliwości ustanowienia uniwersalizmu. Zob. A. Badiou, Święty..., dz. cyt., s. 17-26.

12 A. Bielik-Robson, Na pustyni..., dz. cyt., s. 12.

13 Tamże, s. 10.

14 C. Geertz, Interpretacja kultur. Wybrane eseje, Kraków 2005, s. 69, [cyt. za:] W. Iser, Czym jest antropologia literatury? Różnica między fikcjami woyjaśniającymi a odkrywającymi, „Teksty Drugie” 2007, nr 6, s. 18.

15 E. Gans w deklaratywnym tonie pisze: „Stawiam tezę, że ludzkie doświadczenie, przeciwne doświadczeniu innych zwierząt, W sposób wyjątkowy charakteryzuje się wydarzeniami scenicznymi [scenic events], przypominanymi zarówno indywidualnie, jak i kolektywnie przez reprezentacje, pośród których najbardziej fundamentalne są znaki językowe”. Zob. E. Gans, The scenic imagination. Originary thinking from Hobbes to the present day, Stanford 2008, s. 1.

16 Z. Herbert, Drewniana kostka, [w:] tenże, Studium przedmiotu, Wrocław 1995 (1961).
} 
- „religiami śmierci” czy „kryptoteologiami tanatycznymi” ${ }^{17}$. Ciekawie w tym kontekście wybrzmiewaja, skierowane do Dionizosa, słowa Sokratesa z dramatu Herberta, Jaskinia filozofów:

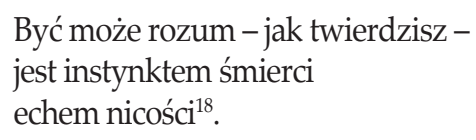

Sugestia Herberta zgadzałaby się z ujęciem starożytnej Grecji zaproponowanym przez Fryderyka Nietzschego w Narodzinach tragedii, a wyrugowanie pierwiastka dionizyjskiego $\mathrm{z}$ dyskursu racjonalistycznego Sokratesa i Platona mogłoby - zaskakująco zbieżnie z refleksją postsekularną - zostać uznane za początek filozofii dogmatycznej jako religii rozumu tożsamej $\mathrm{z}$ religią instynktu śmierci.

Kryptoteologiami tanatycznymi powoduje - wracając do ustaleń autorki Na pustyni - pragnienie „bycia godzącego się ze swą »ontologiczną słabością i i w tym pogodzeniu naśladującego śmierć $^{\prime \prime \prime}$. Za znamiennego dla refleksji nad negatywnością podmiotu w świecie tanatyka uznać trzeba Martina Heideggera, który mimo próby domknięcia źródłowej „,szczeliny” dzięki ontologii zamieszkiwania, twierdzi w Byciu i czasie:

„bycie-w zostało określone jako zamieszkiwanie przy..., zażyłość z... Ten charakter bycia-w został potem bardziej konkretnie uwidoczniony za pomocą powszedniej opinii publicznej Się, które w przeciętną powszedniość jestestwa wprowadza uspokojone poczucie własnego bezpieczeństwa i oczywistość, »bycia-w-swoim-domu«. Trwoga natomiast wyprowadza jestestwo na powrót z jego upadkowego zanurzenia w »świecie «. Powszednia zażyłość załamuje się. Jestestwo jest zindywidualizowane, ale właśnie jako bycie-w-świecie. Bycie-w przybiera egzystencjalny modus »nie-w-swoim-domu«. Niczego innego nie mamy na myśli mówiąc o »nieswojości « ${ }^{20}$.

Heideggerowska "trwoga" to jedno z wielu imion tanatycznej traumy podmiotu w filozofii Zachodu. W tym miejscu należałoby zadać pytanie o imiona popędu śmierci i status negatywności w koncepcji podmiotowości Stachury.

Tanatos jest z pewnością jednym z głównych bohaterów bądź - innymi słowy - najważniejszych towarzyszy, samotnych przeważnie, podmiotów tekstowych u Stachury. Człowiek-ja pozostaje we władaniu negatywności i skazany jest na śmierć, o czym mówią liczne piosenki i wiersze (m.in. Wędrówką życie jest człowieka, Błogo bardzo bẹdę stawił ten dzien, Nie rozdziobia nas kruki, poemat Dużo ognia). W Siekierezadzie trauma śmierci określana jest mianem „ta mgła ta mgła". Mówią o niej liczne wypowiedzi czerpane ze świadomości podmiotu:

„A ta mgła ta mgła? [...] jednak dobrze wiem, doskonale wręcz się orientuję, że śmierć ani na moment mnie nie opuszcza, na głowie wiecznie mi siedzi, na czole mam ją wypisana, przy nodze mojej zawsze wiernie jest"21.

Emil M. Cioran, konsekwentny sceptyk życia i śmierci, dostrzegał istotną relację między popędem tanatycznym a potrzebą wyzwolenia:

„Gdy człowiek rozpoczyna życie odczuciem śmierci, w końcu postępowanie naprzód w czasie zaczyna mu się wydawać powrotną drogą ku narodzinom. Jest to proces odzyskiwania i ponownego

17 Zob. A. Bielik-Robson, Na pustyni..., dz. cyt., s. 40-44.

8 Z. Herbert, Jaskinia filozof6w, [w:] tenże, Dramaty, Warszawa 1970, s. 19-20.

19 A. Bielik-Robson, Na pustyni..., dz. cyt., s. 43.

20 M. Heidegger, Bycie i czas, Warszawa 1994, s. 267. Podkreślenie-A. K.

21 E. Stachura, Siekierezada albo zima leśnych ludzi, Warszawa 1971, s. 21. 
formowania etapów życia. Śmierć, bytowanie, cierpienie i narodziny byłyby momentami tego odwróconego toku. A może jest inne życie, rodzące się na ruinach śmierci?" ${ }^{\prime 22}$.

Podmiot tekstowy Stachury z pewnością odpowiedziałby twierdząco na pytanie Ciorana. O ile konstytutywna dla doświadczenia życia śmierć jest właściwa człowiekowi-ja, o tyle wyzwolenie z oków percepcji prowadzi do powtórnych, autentycznych narodzin ku nowej podmiotowości. Wizję tę przedstawia popularny tekst:

Błogo bardzo sławił będę ten dzień,

Kiedy na nowo się narodzę,

Nawet gdy to będzie śmierci mej dzień.

Może jednak narodzę się wcześniej ${ }^{23}$.

Bardziej pogłębionej filozoficznie wizji śmierci dla świata, która stałaby się narodzinami dla pełnego bycia-w-świecie, proponują końcowe strony Fabuli rasy:

„Pochylił się w sobie niżej, głębiej i zobaczył, że jego lewa ręka jest lewą ręką bestii, a jego dwie nogi są jej dwiema nogami. Pochylił się w sobie jeszcze niżej, [...], już nic nie mogło odwrócić jego uwagi od tego naturalnego, spontanicznego, weselnie śmiertelnego samopoznawania się, od tej samokonstatacji, co była jednocześnie samokontestacja, samonegacja, której towarzyszyła radośćniebywała, nigdy dotąd przez niego nie zaznana) i spojrzał w stronę serca, i spojrzał w serce, i zobaczył... że jego serce... jest jej sercem, sercem bestii. Tak to zobaczył, że cały - od stóp do głów, od pięt po czubki włosów, bez reszty, absolutnie bez reszty - jest jedną straszliwą przerażającą czarną bestią. Rakiem. Rak nieskończenie własnym odrażającym widokiem przerażony, porażony tym samym unicestwia sam siebie"24.

Można zatem mówić o dwóch rodzajach śmierci, z których pierwsza jest chorobą ontologiczna, a druga syntetyzuje negatywność - nawiązując do idealizmu Georga W. F. Hegla na wysokim szczeblu samoświadomości ducha. Zaangażowaniem w pojednanie z bytem u Stachury również rządzi dialektyka, choć pozbawiona wymiaru systemowego. Człowiek-rak musi dążyć do samounicestwienia, by ze śmierci ułomnego ,ja” przejść ku nowemu życiu w zreformowanym podmiocie-będącym-w-zreformowanym-świecie:

„- Kiedy pożrę siebie do szczętu, co wtedy?

- Wtedy się urodzi człowiek-życie, człowiek-nikt.

Człowiek-nikt to właśnie byłczłowiek-Ja, który pożarłswoje wymioty i ichna powrótnie zwymiotował, lecz zaczął pożerać siebie i pożarł siebie do szczętu, i nie zostało z niego nic, nic a nic, i pokazało się źródło, wiecznie od nowa rodzące się źródło wszystkich prawdziwych wiecznie nowych cudów. I prawdziwie zaczął się świat"25.

Mesjanistyczna obietnica utopii, heroiczna i eskapistyczna zarazem, nadaje projektowi podmiotu-nikt, co istotne, wymiar indywidualny, a nie kolektywny, i domaga się wydarzenia fundującego cud „miejsca, które dopiero będzie”. To lepsze miejsce można rozumieć w kategoriach egzystencjalnej fenomenologii przestrzeni Heideggera, a „scena źródłowa” wyzwolenia, choć pojedyncza i indywidualna, skłania się ku możliwości stanowienia uniwersalizmu.

Prawda człowieka-nikt, podobnie jak chrześcijańska prawda świętego Pawła w interpretacji Alaina Badiou, dalekajest od wszelkiego partykularyzmu, nie uprzywilejowuje żadnej grupy, nie

22 E. M. Cioran, Święci i łzy, Warszawa 2003, s. 22.

23 E. Stachura, Błogo bardzo stawił będę ten dzień, w. 1-4.

24 E. Stachura, Fabula rasa. Rzecz o egoizmie, Olsztyn 1985, s. 168.

25 Tamże, s. 69 
domaga się hierarchii wtajemniczonych. Konstrukcja „brata” w Oto wydaje się tekstową figurą apostoła, który - poznawszy praw dę - uruchamia procedurę uniwersalizmu, dając podstawy do tworzenia nowej wspólnoty. Warto zwrócić uwagę w tym miejscu na konstytutywną dla myślenia mesjanistycznego opozycję prawa i wydarzenia. Refleksja Badiou wydaje się czerpać $\mathrm{z}$ ustanowionej przez Derridę dwubiegunowości instytucji i idiomu ${ }^{26}$, jednak podobna logika stanowi znamienny rys każdego programu uniwersalnego mesjanizmu. Jak pisze Lipszyc:

„Pozornie sprawiedliwe prawo - takie samo dla wszystkich - staje się żywiołem opresji. Tak pojętemu prawu przeciwstawiona jest w pismach Benjamina rzeczywista sprawiedliwość, wyraźnie nasycona potencjałem wyzwolicielskim i mesjańskim. Jak zobaczymy, podobną opozycją posłuży się Emmanuel Lévinas, jak również Jacques Derrida. Także dla Lévinasa prawo stoi po stronie myślenia immanentystycznego, które ignoruje otwartą na transcendencję perspektywę etycznej sprawiedliwości"27.

Gest wyzwolenia i stanowienia jednostkowej prawdy musi mieć charakter idiomatycznego wydarzenia, rozrywającego immanencję zastanej rzeczywistości, rządzonej przez prawo. Podmiot tekstów Stachury kilkukrotnie posługuje się przeciwstawieniem wyjątku i reguły, jak w poniższym fragmencie opowiadania Wesele:

„i ach, pomóż wspomóż dopomóż ty - jedyny jedyniutki wyjątku czuły - odeprzeć tłumne armie reguły, i ach, cudne manowce, dźwignać się, powstać, z-podeptanych-przez-demony-powstać, z fatalnego opętania się odpętać, się rozpętać i oderwać dwoje ludzi - co jak jeden mąż - od beznadziejnego bezwiernego zdradliwego kręgu i naprzód iść, naprzód zawsze i niesłychanie, ku polanie, skąd magiczne magnetyczne wołanie, ale już niema naprzód, mówią demony, już tylko w kółko jest, w miejscu, w miejscu ostatniej zagłady, w miejscu tego miejsca już tylko duchem będziesz krążył i sam siebie wiecznie straszył"28.

Wyraźnie podmiot dokonuje tu projekcji wyzwolicielskiego aktu samonegacji człowieka-raka, powstania nowego „nikogo" bez tożsamości ,,ja”, upatrując w nim „wyjątku” od reguły, absolutnego idiomu przeciwstawionego opresyjnej instytucji. Projektowana rzeczywistość, która stać się może - w utopijnym założeniu - udziałem zreformowanego podmiotu, stanowić będzie jednak nową możliwość prawa powszechnego (jak w myśleniu Kanta). Na ten paradoks wydarzenia i prawa powstałej wspólnoty wskazuje Badiou:

„Kluczowe dla nas jest to, że owo paradoksalne połączenie podmiotu bez tożsamości i prawa bez podstawy umożliwia umieszczenie uniwersalnego nauczania w historii. Bezprecedensowy gest Pawła polega na wyrwaniu prawdy z uścisku wspólnoty"22.

W tekstach Stachury mowa oczywiście jedynie o projekcji stanowienia uniwersalnej prawdy ludzi-nikt. Wskazanie na punkty styczne z programem św. Pawła pozwala jednak dostrzec etyczny i emancypacyjny wymiar wyrwania podmiotu z jego partykularnej tożsamości. O uniwersalizmie projektu Stachury świadczyć może fragment:

„Obłędem jest być nieprawym, będąc prawym ciałem obdarzonym, albowiem ciało - każde jest prawe. [...] Obłędem jest poznawać świat przez mikroskop czy teleskop, będąc obdarzonym taką cudownościa, jaką są żywe widzące oczy"30.

26 Na temat negocjowania między idiomem a instytucją zob. D. Attridge, Ta dziwna instytucja zwana literatura (rozmowa z Jacques'em Derrida), [w:] Nycz R. (red.), Dekonstrukcja w badaniach literackich, Gdańsk 2000, s. 17-73.

27 A. Lipszyc, Ślad judaizmu..., dz. cyt., s. 89.

28 E. Stachura, Wesele, [w:] tenże, Się, Warszawa 1988, s. 15-16

29 A. Badiou, Święty..., dz. cyt., s. 18. Podkreślenie - A. K.

30 E. Stachura, Oto, [w:] tenże, Wiersze pozostałe, Toruń 2000, s. 124. 
Ludzie-ja nieustannie podlegają różnicowaniu z uwagi na partykularne tożsamości, jednak obietnica nowego podmiotu znosi te podziały w imię „prawego" ciała i „żywych, widzących” oczu, które przynależą każdemu. W utopijnej przyszłości Heideggerowskie „miejsce” podmiotu byłoby równoznaczne z widzeniem „,całej jaskrawości”. Wypada przytoczyć długi, poetycki fragment wieńczący Oto jako zapowiedź możliwego do doświadczenia "tu” $i$,„teraz", bycia-tu-oto:

$$
\text { ŻYCIE }
$$

kwiat ładu w pełnym rozkwicie

mieniąca się nieustanną nowościa, nigdy nie więdnąca

róża świata w wieńcu królestwa niebieskiego

najdrobniejsza, najnieznaczniejsza polna stokrotka

oczywistość

rzeczywistość

zjawa realna

cała jaskrawość

cudne manowce

widok nad widoki

kropka nad ypsylonem

biała lokomotywa na czarnym węglu

acternum mobile

człowiek

człowiek cały

człowiek każdy

dziecko samo siebie rysujące

nie do pokalania dziewiczość

nie do pokonania bezbronność

bezwysiłkowość, naturalność, spontaniczność, wolność,

zdrowie, piękno, szczęście

księżyc księżyców a słońce słońc

żywy ogień

niewidzialne w postaci widzialnej

Wszystko ${ }^{31}$

Podmiot-ja uwikłany w immanencję rzeczywistości mógł doświadczać sporadycznych epifanii, rozproszonych objawień, $w$ których - przez szczeliny istnienia - dostrzegał transcendentne wymiary egzystencji, goniąc Zjawę Realną i Białą Lokomotywę. Fundujące nową rzeczywistość ponowne narodziny podmiotu bez tożsamości zaprowadzają jednak rewolucję $\mathrm{w}$ byciu-w-świecie i przenoszą do innego porząaku doświadczania, gdzie transcendencja jest "tu oto" w swojej jaskrawości, a hierofanie tracą sens.

\section{Ż̇̇oBA Po PODMIOCIE. ZAKoŃCZeNIE}

By zweryfikować potencjał obietnicy wyzwolenia, trzeba powrócić do wątków poruszanych we wstępie. Podmiot u Stachury, podobnie jak u Derridy, to ciągła obietnica „opóźnionego

$31 \quad$ Tamże, s. 146-147. 
nadejścia" ${ }^{32}$. Końcowe wnioski Fabuli rasy dobrze uzmysławiają uwikłania ,ja” tekstowego:

„I tu się zaczyna, prawdziwie zaczyna: fabula rasa. Coś, co można opisywać, ale co zawsze pozostanie tylko opisem, nigdy nie będzie nieopisaną rzeczywistością. Bo nie da się fabrykować literatury z czegoś, co nie jest fabuła, a jest skrzącą się, mieniącą się, wiecznie nową a nieprzemijająca, nieśmiertelnie żywą prawdą i prościutką jak dzień dobry"33.

Opis i literatura nie mogą wyrazić „całej jaskrawości” rzeczywistości - to rzecz oczywista. A jednak można, a - według początkowych słów Derridy - nawet trzeba, pisać i fabrykować, tworzyć fabuły. Czy jednak fabula rzeczywiście jest rasa? Ja jest przecież uwikłane w tekst i nie istnieje bez pisma, bez konstytuującej różnicy, która pozwala mu zaistnieć jako tożsamości, czyli narodzić się ",rakiem” po to, by ten mógł się unicestwić i przerodzić się w „nikogo”. Bez tego wzrastania „ducha”, świadczącego o trwałości kategorii filozofii zachodnioeuropejskiej, nie byłoby obietnicy wyzwolenia, a bez niej nie byłoby epifanii. Przecinanie porządku rzeczywistości przez transcendencję jest warunkowane w koncepcji podmiotu przez możliwość samostanowienia absolutnej tożsamości. Bez pisma nie byłoby zatem różnicy, a bez różnicy nie byłoby podmiotu. W Oto wyczytać można:

„Różnica jest jedna i jedyna: pomiędzy Wymysłem a faktem, pomiędzy Słowem a pozasłowiem, pomiędzy słowem bezcielesnym a słowem cielesnym, pomiędzy opisującym się bez końca opisem a nieopisującą się i nie do opisania rzeczywistością, pomiędzy rozpaczliwym poczuciem czasowego Trwania a radosna, ekstatyczną oczywistością wiecznego bycia, pomiędzy fałszywie i majakliwie śpiącym a prawdziwie, jasno obudzonym, pomiędzy nieurodzonym a urodzonym, pomiędzy martwym (martwym, nie umarłym) a żywym" ${ }^{\prime 34}$.

Różnica jest tym, co warunkuje przygodność doświadczania podmiotu, jak również jego dążenie do wyrwania się z własnego człowieczeństwa, wyciągnięcia z bagna za włosy, wzorem barona von Münchhausena. Słusznie zaznacza Bielik-Robson, iż owa

„nieskończona oscylacja to nic innego jak fichteańskie Schweben, ruch, w którym Ja nigdy nie może stać się w pełni obecne dla siebie samego, zawsze się od siebie oddalając w procesie autoalienacji”35.

Dialektyka o rodowodzie niemieckim jest istotną przesłanką dla ruchu świadomości podmiotu, jednak różnica „pomiędzy Wymysłem a faktem” utrzymuje tekstowe „,ja” w nieustannym, horyzontalnym drganiu znaczeń. „Pomiędzy opisującym się bez końca opisem a nieopisującą się i nie do opisania rzeczywistością" nie ma możliwości wyniesienia podmiotu w ruchu wertykalnym, a efekt inskrypcji staje się efektem aporii i „permanentnej żałoby”. Ja, wstępując w pismo i zyskując przestrzeń możliwości wypowiedzenia, jedyny możliwy sposób zabrania "głosu” w obliczu dekonstrukcji fonocentryzmu, poddaje się „podeptaniu przez demony" - jak w opowiadaniu Wesele - i nie powstaje ze słowa w pozasłowie. Od żałoby po podmiocie zaczyna się fabrykowanie fabuł i (nie)opisanie śmierci fundującej tekstowe przygody ,ja”, które „,nawet nie wie, że już dawno umarło" ${ }^{\prime 36}$.

\footnotetext{
32 A. Bielik-Robson, Na pustyni..., dz. cyt., s. 99.

33 E. Stachura, Fabula rasa..., dz. cyt., s. 170.

34 E. Stachura, Oto..., dz. cyt., s. 127-128.

35 A. Bielik-Robson, Na pustyni..., dz. cyt., s. 100

36 Tamże, s. 98
} 


\section{LITERATURA PODMIOTU}

Cioran E. M., Święci i łzy, Warszawa 2003.

Herbert Z., Jaskinia filozofów, [w:] tenże, Dramaty, Warszawa 1970.

Herbert Z., Wiersze zebrane, Warszawa 1982.

Stachura E., Fabula rasa. Rzecz o egoizmie, Olsztyn 1985.

Stachura E., Wiersze pozostałe, Torun 2000.

Stachura E., Siekierezada albo zima leśnych ludzi, Warszawa 1971.

Stachura E., Się, Warszawa 1988.

\section{LITERATURA PRZEDMIOTU}

Badiou A., Święty Paweł. Ustanowienie uniwersalizmu, Kraków 2007.

Bielik-Robson A., Na pustyni. Kryptoteologie późnej nowoczesności, Kraków 2008.

Culler J., W obronie nadinterpretacji, [w:] Eco U. (red.), Interpretacja i nadinterpretacja, Kraków 1996.

Gans E., The scenic imagination. Originary thinking from Hobbes to the present day, Stanford 2008.

Heidegger M., Bycie i czas, Warszawa 1994.

Iser W., Czym jest antropologia literatury? Różnica między fikcjami wyjaśniającymi a odkrywającymi, „,Teksty Drugie” 2007, nr 6. Lipszyc A., Ślad judaizmu w filozofii XX wieku, Warszawa 2009.

Markowski M. P., Antropologia, interpretacja, humanizm, [w:] Markowski M., Nycz R. (red.), Kulturowa teoria literatury. Główne pojęcia i problemy, Kraków 2010.

Markowski M. P., Czarny nurt. Gombrowicz, świat, literatura, Kraków 2004.

Nycz R., Sylwy wspótczesne, Kraków 1996.

Attridge D., Ta dziwna instytucja zwana literaturą (rozmowa z Jacques'em Derridą), [w:] Nycz R. (red.), Dekonstrukcja w badaniach literackich, Gdańsk 2000.

\section{Słowa kluczowe}

Edward Stachura, postsekularyzm, literatura, interpretacja, nowoczesność, kryptoteologie, Agata Bielik-Robson

\section{STRESZCZENIE}

Artykuł ma na celu usytuowanie postsekularyzmu na mapie fundamentalnych zmian w polskim dyskursie literaturoznawczym ostatnich kilkunastu lat. Posiłkując się refleksją Agaty Bielik-Robson i Adama Lipszyca, najważniejszych rodzimych znawców tematu, zaprezentowany zostanie zarys kierunków kryptoteologicznych interpretacji twórczości poetyckiej i prozatorskiej Edwarda Stachury.

\section{Post-Secularism and literature. The example Of Edward Stachura}

\section{Keywords}

Edward Stachura, post-secularism, literature, interpretation, modernity, crypto-theologies, Agata Bielik-Robson

\section{Summary}

The paper's aim is to situate post-secularism on the map of fundamental transitions in the Polish literary theory discourse of the last several years. Referring to the reflections of Agata Bielik-Robson and Adam Lipszyc, the most important of the native authorities on the topic, the outline of the directions of the crypto-theological interpretations of the poetry and prose of Edward Stachura will be presented. 